\title{
"People Nowadays Will Take Everything They Can Get": American Perceptions of Basic Income Usage
}

\author{
Leah Hamilton $^{1}$ (D) Meric Yorgun ${ }^{1} \cdot$ Allison Wright $^{1}$
}

Accepted: 18 July 2021 / Published online: 28 July 2021

(c) The Author(s), under exclusive licence to Springer Nature Switzerland AG 2021

\begin{abstract}
Universal basic income (UBI) is a centuries-old policy proposal in which every citizen is granted a regular cash payment to provide basic security. One defining concept of a UBI is that it is unconditional, unlike most modern social welfare programs. While decades of pilot data suggest UBI to be superior to traditional means tested assistance, public support is divided and heavily based on stereotypes of dependency and negative consumption effects. A mixed-method research design was utilized to explore the projected behavioral response to UBI of current and former recipients of traditional assistance, in regard to themselves and others. Responses indicate that the majority of participants would not alter their current work arrangements and would rather plan for future financial stability while assuming that other Americans would quit working and spend the money irresponsibly. These results suggest that even among welfare recipients, neoliberal and conservative narratives of dependency and irrationality persist.
\end{abstract}

Keywords Basic income $\cdot$ Welfare $\cdot$ Neoliberalism

\section{Introduction}

Universal basic income (UBI) is an old idea that can be traced to the sixteenthcentury document, Sir Thomas More's Utopia (2003, 1516). While not new, the concept has enjoyed a resurgence of interest in the last two decades with rising concerns of income inequality, unending poverty, and job losses due to automation. The COVID-19 pandemic and resultant financial effects have created a new international focus on the need for an unconditional economic baseline for all. However, this new attention has multiplied existing misconceptions. Many similar but fundamentally different concepts are referred to as basic income. In order to prevent such misconceptions, proponents of basic income generally agree upon

Leah Hamilton

hamiltonl@appstate.edu

1 Appalachian State University, Boone, USA 
the definition created by the Basic Income Earth Network (BIEN). According to BIEN (2020), "a basic income is a periodic cash payment unconditionally delivered to all on an individual basis, without means-test or work requirement." This definition has been agreed upon because it covers the five fundamental characteristics of basic income.

First of all, "basic" income suggests that the amount given should be sufficient to provide basic security allowing people to meet their basic needs such as food, shelter, and clothing. However, it is important to clarify that the amount of basic income is not predetermined, and the definition does not include any net amount (Van Parijs, 2004). Secondly, a basic income should be "paid in cash," not in kind, to avoid any restrictions on the use of income. Moreover, this cash transfer needs to be made "regularly" so that people can predict future income, and therefore make long-term plans. Unlike most traditional welfare policies and social benefits, basic income must be paid "individually." This individualistic nature is an essential difference between UBI and other social schemes. According to advocates, only in this way, can cash transfers provide true emancipation. Another characteristic is "unconditionality," possibly the most controversial element of UBI. Again, unlike conventional cash transfers, UBI should be unconditional, without means-test or work requirement. Unconditionality eliminates the stigmatization associated with modern "welfare." Furthermore, advocates argue that poverty traps can be avoided if people do not have to worry that they will lose their social benefits as income increases. Finally, (universal) basic income should be "universal." Universality is advocated as it arguably leads to greater social cohesion and cooperation among people which again, other social benefits fail to achieve (or even lead to stigmatization). Therefore, it is one of the most important elements of UBI that differentiates it from other schemes (Standing, 2017).

While 60 years of pilot data suggest that UBI can decrease poverty, improve recipient outcomes, and have a net positive effect on the economy (Marinescu, 2017a, 2017b; Nikiforos et al., 2017), support for the idea among Americans remains split (Gilberstadt, 2020). However, little previous research has explored why Americans do or do not support UBI. We hypothesize that entrenched narratives of "welfare queens," misuse of public funds, and welfare dependency may influence these positions. In order to further explore American perceptions of UBI and inform public policy discourse, we surveyed 50 Americans regarding what they would do with an unconditional \$1,000 per month and what they thought others would do with the same amount. This amount was chosen as it matches Andrew Yang's "Freedom Dividend" proposal and several other popular UBI policy proposals. Furthermore, we chose to only survey American adults who were current or former recipients of traditional assistance programs as they might offer a unique perspective based on their experiences. We find that respondents predict using the money to gain more stable financial footing via homeownership, higher education, or small business development, but believe that other Americans would use the money to quit their jobs and make non-essential purchases. 


\section{Literature Review}

\section{Brief History of Basic Income}

Before reaching its final version as an "unconditional basic income," the idea of a universal minimum income guaranteed by the state emerged centuries ago. There are actually three different historical roots of the concept of basic income. First, the idea of a minimum wage first emerged at the beginning of the sixteenth century. Later, the allocation of an unconditional one-time grant emerged at the end of the eighteenth century, while the combination of the two, the (unconditional) basic income, was first articulated in the middle of the nineteenth century (BIEN, 2020).

Although the origin of the concept is often attributed to Sir Thomas More's Utopia, Juan Luis Vives (1492-1540) is now known as the original intellectual of basic income. In his work On Assistance to the Poor, published in 1526, Vives proposed to provide a certain minimum public assistance for everyone living within the municipality boundaries. According to Vives, this public assistance should be given to poor people only if they were willing to work. While not successful, Vives' work inspired the emergence of The English Poor Laws in 1587-98. In the eighteenth century, the idea of reducing poverty again came to the fore amidst the French Revolution. The Marquis de Concordet (1743-1794) proposed an idea that he called a "basic endowment." Later, Thomas Paine (1737-1809) suggested that the earth is the common property of the human race and every owner who cultivates land has a rent debt to society. This "groundrent" must be paid to every person upon turning 21 (Standing, 2017).

Charles Fourier (1772-1837), an early utopian socialist, argued that basic human rights such as hunting, fishing, and letting one's cattle graze were violated by civilization and that people should be provided with a "subsistence allowance" in exchange for their direct access to natural resources. Another utopian socialist Joseph Charlier (1816-1896) objected to Fourier's subsistence allowance on the grounds that the state could interfere too much. Instead, he suggested calculating a "regional dividend" by calculating the rent of all real estate and paying this to every citizen. On the other hand, John Stuart Mill (1806-1873), in his Principles of Economy, supports Fourier's proposal, but adds that private property and inheritance can coexist with a subsistence allowance. According to Mills, first, a certain subsistence is distributed to each member of the society from the total production. The remaining surplus can be distributed between labor, capital, and talent at predetermined rates (History, BIEN).

In his book Roads to Freedom (2013), British thinker Bertrand Russell (1872-1970) brought renewed attention to basic income by proposing it as a means to social justice. He argued that everyone should be paid a certain minimum income and that after completing an education, work should be voluntary rather than required for membership in society. In the 1960s, the American economist Robert Theobald (1929-1999) predicted that in the future, increasing automation will replace many jobs, and therefore, a basic income by the state will be inevitable for all. Another form of basic income was the famous "negative 
income tax" introduced by Nobel Prize-winning economist Milton Friedman (1912-2006) in his book Capitalism and Freedom (2009). President Richard Nixon even proposed to replace many federal welfare programs with a negative income tax (Hughes, 2020). Several government-funded basic income experiments were conducted both in the USA and Canada in the 1960s and 1970s. As a result of growing interest in the idea, in 1986, basic income supporters founded the Basic Income European Network (BIEN, 2020) in Belgium. Today, BIEN is known as the Basic Income Earth Network and continues to conduct research and organize meetings on basic income (BIEN, 2020).

Interest in basic income fizzled in the USA as early pilot data suggested an increase in divorce among recipients. Decades later, researchers discovered that this was a calculation error, but the damage had already been done (Marinescu, $2017 \mathrm{a}, \mathrm{b}$ ). However, since the 2000s, UBI has regained momentum due to increased inequality, the growth of automation and artificial intelligence, and the COVID19 pandemic. Most recently, Andrew Yang's 2020 candidacy for the American presidency, with a campaign focus on basic income, introduced UBI into mainstream political discourse. Basic income pilots are once again launching around the world and consistently associate UBI with decreased poverty, little to no change in employment, increased school enrollment and attendance among the children of recipients, more positive family interactions, and improved mental and physical health (Hasdell, 2020).

\section{What Do Americans Think About Basic Income?}

Although the popularity of basic income has been on the rise in recent years, American opinion continues to be divided. According to a 2017 Gallup poll, 52\% of American adults are against UBI while 48\% support it (Freeland, 2019). A more recent survey conducted by the Pew Research Center produced similar results. When American adults were asked if they would support a UBI of $\$ 1000$ per month provided by the federal government for all adult citizens, whether or not they work, $54 \%$ opposed the proposal (Gilberstadt, 2020). Another poll by Zogby Strategies (2017) found that $40 \%$ would be in favor of UBI while $35 \%$ would be against. In this poll, $25 \%$ of people remained undecided. Similar results were demonstrated by the IPSOS (2017) international survey, while 49\% of Americans supported UBI, 26\% were opposed, and $25 \%$ were undecided.

Age, race, gender, education, income level, and political opinion are all important factors that influence one's opinion regarding UBI (Gilberstadt, 2020). People under 30 report strong support for UBI with $67 \%$ in favor (33\% against); however, this rate drops dramatically among those 65 and older: only $26 \%$ support UBI while a majority (72\%) are against it. Another study supports this trend: $41 \%$ of those under 53 (the sample age) favor UBI compared to only 33\% of those over 53 (Freeland, 2019). When it comes to race, a majority of Black (73\%) and Latinx (63\%) adults are in favor of basic income, compared to only 35\% of White adults (Gilberstadt, 2020). Additionally, women tend to be more supportive (40\%) of UBI than men (35\%). Education level of people also seems to be influential on people's opinion. 
People with bachelor's degrees are more likely to be against UBI (46\% against) than those with less education (37\% against) (Freeland, 2019). Further, people with lower incomes are more supportive of UBI (63\% in favor compared to $31 \%$ among higher income households).

Perhaps the most fundamental trend is related to one's placement on the political spectrum. There is strong opposition (78\%) to an unconditional, universal cash transfer of $\$ 1000 /$ month among Republicans while the majority of Democrats $(66 \%)$ are supportive of this proposal. However, the results from both parties also vary according to age, race, and income level. Although most Republicans in all age groups oppose UBI, $41 \%$ of Republicans aged 18 to 34 favor it. We also see the same trend among Democrats: adults 18 to 34 show much higher support than older people. Moreover, income level seems to be highly influential for both parties. Forty-three percent of Republicans with low incomes favor UBI, while support sharply decreases to $17 \%$ for middle income groups and $8 \%$ for higher income Republicans. While there is a similar trend among Democrats, overall support for UBI is much higher. We also see racial differences among Democrats. Again, the majority of Black and Hispanic Democrats support UBI (77\% and 70\%, respectively), compared to $61 \%$ of White Democrats (Gilberstadt, 2020).

\section{Understanding the Assumptions}

When we look at the possible reasons why people might oppose UBI, especially a majority of Republicans, we find some general assumptions as follows: "Cash transfers would make people lazy and dependent" or "People would spend money on alcohol, tobacco or 'bad habits"' (Thompson, 2018), despite a significant body of evidence to the contrary (Hasdell, 2020; Marinescu, 2017a, 2017b). It is therefore worthwhile to trace the roots of these political tropes, beginning with two central ideologies: Protestantism and capitalism. Together they lay the foundations of political thought that has shaped American society for centuries.

Max Weber once famously claimed that western capitalism could only emerge thanks to Protestant ethics and values, specifically the Calvinist doctrine of asceticism and predestination (Crossman, 2019). In the early church, the Catholic idea that we could earn our place in heaven through good work was shared among Christians but was later rejected with the birth of Protestantism. For Protestants, salvation was predestined and it was possible to perceive those who were elected by simply observing their way of life. The two important marks to watch were the person's hard work and frugality. In this regard, the qualifications of hard work, frugality, and discipline were attributed to being chosen. Weber argued that these attributions, values, and eventually the associated mindset created space for capitalism to thrive in the West.

Then, with the rise of capitalism and classic economy theories, reason was emphasized for one's means to survive, i.e., the degree to which one exerts personal effort and uses the guidance of his own reason determines whether he thrives or fails. In other words, there were no structural flaws, only individuals' mistakes (Rand, 1967). These conditions set the foundation for the emergence of a new sort of ethos which would later be called the "American Dream." The message of these 
ideals was clear: no matter where or in which conditions you were born, each individual has the right and freedom to seek prosperity and happiness. With its emphasis on hard work and dedication, this dream promised the prescription to achieve financial success and high positions in society.

This emphasis on personal responsibility crossed the political aisle with the rise of neoliberalism in the 1980s and became the central approach toward social policies (Jansson, 2014). In the neoliberal agenda, welfare policies including cash transfers are criticized as going against core American values by promoting laziness and dependency. Classical economic theories and neoliberalism argue that each individual is responsible for their own life and must work hard to earn their positions in life (Goeury, 2016). If they do not act rationally and fail to take care of themselves, this could be only due to their own wrongdoing. "Handouts" and benefits therefore diminish incentives to work, reward laziness, and ultimately create dependency on the state (Hamilton, 2016). From this perspective, people are discouraged from taking control of their own lives, which is unfair to those who persevere and work hard since they are the ones who carry the extra burdens of other people's failure.

In addition, it is argued that when people (especially the poor) receive unconditional money, they use it for negative purchases like alcohol and tobacco since, through their failures in the capitalist market, they have proven their incapacity for rational decision-making (FAO, 2016). Moreover, conservative philosophy claims that children who grow up with parents who do not earn what they have will later embody this idleness as a social norm in adulthood. Then, they will become the next recipients of social programs, creating the "culture of dependency" (Hanna, 2019). But do these assumptions actually present reality? Are they supported by evidence or do they exist as political mythology?

\section{What Does the Evidence Actually Say?}

One of the most important advantages of UBI is that it bypasses the substitution effect, which means people do not lose money when they start to earn more as in most conditional welfare programs. In this way, it creates a potentially strong incentive for work and greater earnings, which has born out over 60 years of cash transfer pilot data (Marinescu, 2017a, 2017b). A Stanford University cross-synthesis of reviews (Hasdell, 2020) found that across sixteen systematic reviews of international basic income pilots, there is little to no impact on the employment outcomes of recipients. It should be noted that none of these pilots meets the exact UBI conditions discussed before, which are universal, unconditional, individual, regular, and paid in cash. However, they still provide some vital insights for a possible future with a true UBI.

Beginning in the 1960-1970s, Negative Income Tax (NIT) experiment with more than 10,000 participants in seven states (monthly amounts ranging from $\$ 1,453$ to $\$ 4,037$ for a family of four in 2013 dollars) discovered a slightly negative impact on working hours, but the impact was found to be statistically insignificant (Burtless, 1986; Robins, 1985). Often, when work does decline, it is replaced 
by increased caregiving tasks (Hasdell, 2020). In the NIT trials, the largest reductions of work efforts were seen among single mothers (Widerquist, 2005).

In the 1990s, the North Carolina Eastern Band of Cherokees' Casino Dividend, which provided unconditional cash transfers to 16,000 tribe members (\$4,000-\$6,000 per year), had no labor supply effect over the ten-year period of examination (Akee et al., 2010). But a much more interesting result was revealed in the casino dividend study: The children who received casino payments were less likely to consume alcohol or cannabis when they became adults. Moreover, significant reductions were observed in smoking and obesity as well as decreases in drug-dealing activities among youth recipients (Marinescu, 2017a, 2017b). An analysis of the Alaska Permanent Fund, in which every eligible citizen of Alaska receives annual oil dividends, also demonstrates little to no effect on work (Jones \& Marinescu, 2020).

A 2012 pilot program in Madhya Pradesh, India, gave 127 households 300 rupees per month for every adult and 150 rupees per month for every child. The pilot revealed stunning outcomes in terms of basic income's impact on alcohol consumption and work. First, a positive economic effect was found in terms of a higher level of work, productive labor, earned incomes, and assets. Regarding consumption behavior, basic income did not increase alcohol consumption; on the contrary, it actually decreased the average amount spent on alcohol! Recipients explained that before the experiment, there was not enough work, and therefore, men spent their time sitting and drinking. Whereas with basic income, they became busier as they used the money for production, and in doing so, they had less time for vices. Furthermore, a survey four years after the Madhya Pradesh experiment found that $54 \%$ said their drinking decreased and one-third said it remained the same while a small percentage said it increased (Davala et al., 2017). Finally, a recent experiment in Finland also found no impact on paid employment. However, the recipients reported better overall health and economic well-being ("Results of Finland's basic income experiment," 2020).

Longer and permanent experiments are needed with the exact conditions of UBI (especially universality) to understand its true impact at the micro and macro levels. For example, would behavioral responses to basic income be different if recipients knew the policy would be made permanent? Furthermore, how would the macroeconomy be affected if everyone had an extra $\$ 1000$ monthly? A model conducted by the Roosevelt Institute predicts that basic income would grow the economy, reduce unemployment, and increase wages without increasing inflation (Nikiforos et al., 2017).

Still, the assumptions that basic income results in laziness and negative consumption behaviors persist despite a growing body of evidence to the contrary. In order to build the case for larger experiments of unconditional cash transfers, it may be useful to understand what exactly recipients would do with such a benefit. We have seen that basic income does not lead to an increase in negative spending, but how would Americans spend a no-strings-attached monthly benefit? Conversely, how do Americans think others would spend it? Little to no previous research explores these questions. This latter question will be useful to better understand the political barriers facing UBI advocates. 


\section{Method}

\section{Design}

The current mixed-methods study includes both qualitative and quantitative survey responses of US citizens who self-reported as currently or ever receiving either Temporary Assistance to Needy Families (TANF; cash assistance), the Supplemental Nutrition Assistance Program (SNAP; food assistance), Unemployment Insurance (UI; for temporarily unemployed workers), or Supplemental Security Income (SSI; for persons with long-term disabilities). This population was selected in order to understand the perspectives of those who already had experience with cash transfer programs, which might give them a different perspective than the average citizen. Participants were asked what they would do if instead of traditional public assistance, they received an unconditional basic income of $\$ 1,000$ per month that came with no income limitations, and no requirements to seek/maintain employment or other similar eligibility criteria. They were also asked what they thought most Americans would do with the same basic income and lack of limitations. The study was approved by the university's Institutional Review Board as it involved minimal risk to participants.

\section{Participants}

Amazon's Prime Panels platform is an increasingly popular recruitment tool in social science research which can provide diverse respondent samples and highquality data (Chandler et al., 2019). Prime Panels was used to recruit a targeted sample of 50 adult $(18+)$ American citizens, although two participants were ultimately eliminated from the analysis as they had not received one of the previously described programs, bringing the final sample to 48 participants. Amazon's MTurk and Prime Panel platforms are useful tools when recruiting vulnerable populations such as former welfare recipients because respondents have self-selected to participate and anonymity is ensured (Smith et al., 2015).

The sample size (50) was chosen for two reasons. First, because little to no previous research has explored our particular research questions, this survey was designed as a pilot. Respondents were allowed a write-in "other" option in order to inform future research instruments. Secondly, because the survey included openended qualitative questions, the sample size was limited in order to ensure the manageability of data analysis. While there is no clear agreement on the ideal sample size for qualitative research (Boddy, 2016), grounded theory research can include 20 to 60 participants, with a goal of reaching data saturation (Creswell \& Poth, 2017).

\section{Procedures}

The survey launched in June 2019. Respondents were told that the survey would take 10-20 min. In practice, participants spent an average of 6.2 min completing the survey, but in some cases only $2.5 \mathrm{~min}$ and in others as much as $10 \mathrm{~min}$. Respondents were 
reimbursed \$2 for their participation. This amount was chosen to compensate participants fairly but without coercion. Participants were asked a series of questions regarding their demographics, experiences with public assistance, and their attitudes towards a universal basic income. Identifying information was not collected (See Appendix 1 for the full survey).

When asked what they would do with a basic income and what they thought others would do, respondents were asked to choose one of the following options: (a) Quit working or seeking work; (b) Reduce working hours; (c) Continue working as they do now; (d) Apply the money towards major financial goals such as education, homeownership, or a small business development (please explain); (e) Apply the money towards a major consumer purchase, such as a vehicle, television, or appliance (please explain); or (f) Other (please explain). These options are not necessarily mutually exclusive. For example, one could hypothetically continue working and also save for a major financial goal. However, respondents were asked to choose one option only in order to gauge their first reaction to the question.

Data analysis of the quantitative questions was conducted via Excel spreadsheets as the analysis was relatively simple. In vivo qualitative coding (Creswell \& Poth, 2017) was undertaken by hand. When coding for qualitative themes, some respondents did not sufficiently differentiate between what they would do versus what they thought others would do. Furthermore, some respondents described what they thought Americans should do with a basic income. In both circumstances, these responses were not included in qualitative coding.

\section{Validity and Reliability}

In the absence of validated scales for the current research question, several procedures were undertaken to improve the validity and reliability of the results. First, respondents were asked to explain their responses to quantitative questions in order to ensure that they were truly paying attention to the questions and not responding at random, a common hazard of online research (Litman \& Robinson, 2020). Furthermore, the discussion section will include an analysis of how these findings compare to previous research in order to triangulate results. Finally, the authors have attempted to fully explain the procedures here in hopes of improving future replication.

\section{Findings}

\section{Demographics}

Men made up just over half (56\%) of the sample and $86 \%$ were aged between 21 and 49. The sample was heavily white $(81 \%)$ and either divorced, separated, or never married (77\%). The majority of the participants worked full-time (67\%) and a further $25 \%$ part-time. Participants had a wide range of educational qualifications: $35 \%$ had a bachelor's degree, $25 \%$ some college but no degree, and $19 \%$ a high school diploma or GED. Household gross income was below $\$ 60,00$ for most respondents (77\%). See Table 2 Appendix 2 for full demographics. 
The sample is quite similar to national surveys of public assistance recipients (Foster \& Rojas, 2018). In 2014, adult recipients of the primary public assistance programs (Medicaid, SNAP, TANF, SSI, and housing assistance) reported an average age of 39.6, average household income of $\$ 65,939$, and an array of educational attainment $(35.9 \%$ bachelor's degree, $30.7 \%$ some college, and $21.8 \%$ with a high school diploma or equivalency). Nationally, whites are similarly overrepresented, comprising $86.4 \%$ of public assistance recipients.

\section{Quantitative Results}

When asked what they would do if they received an unconditional basic income of $\$ 1,000$ per month that came with no income limitations, no requirements to seek/ maintain employment or other similar eligibility criteria, $43.75 \%$ of former welfare recipients reported that they would continue working as they do now, $10.42 \%$ would reduce their hours, and only $4.17 \%$ would either quit working or looking for work. Another $39.58 \%$ said they would apply the money towards major financial goals such as education, homeownership, or small business development.

Interestingly, when asked what they thought other Americans would do with a basic income, these same respondents had very different perspectives. Nearly $44 \%$ assumed that others would reduce work or quit working altogether. Only $27 \%$ assumed that others would continue working, compared to the $43.75 \%$ who would continue working themselves. A mere $10.42 \%$ thought others would apply the money to major financial goals, a quarter of those saying they would do so themselves. Finally, while none of the respondents said they would apply the money towards a major consumer purchase, such as a vehicle, television, or appliance, $16.67 \%$ assumed that others would. See Table 1 for a full breakdown.

\section{Qualitative Themes}

When asked to explain their assumptions about other Americans, several themes arose. First, eight respondents assumed that a basic income would simply enable laziness among recipients. For example, one respondent said "I have noticed that people now a days [sic] will take everything they can get and then some like they are owed" and another explained that "Americans can be lazy so they'll do anything to reduce time at work." Interestingly, another said that "I don't know anyone like this but...A lot of folks want something for nothing."

Conversely, seven respondents agreed that Americans would work less if given a basic income, but did not interpret this as a negative. They explained that the policy might allow people to work less and enjoy life more. One responded, "I think people would stress less about work, and work a little less to enjoy life more." Others said, "I think more people would focus on family time and pursuing hobbies. It would boost overall morale in the country, I think" and "I think most people would reduce their working hours because they would worry a little less about how much money they made. It would allow them to relax a little bit more." 
Table 1 Quantitative responses

\begin{tabular}{|c|c|c|c|c|}
\hline \multirow[b]{2}{*}{ Answer } & \multicolumn{2}{|c|}{$\begin{array}{l}\text { If, instead of } \\
\text { traditional } \\
\text { public assis- } \\
\text { tance, you } \\
\text { received an } \\
\text { unconditional } \\
\text { basic income, } \\
\text { what would } \\
\text { you do? }\end{array}$} & \multicolumn{2}{|c|}{$\begin{array}{l}\text { If, instead of } \\
\text { traditional } \\
\text { public assis- } \\
\text { tance, every } \\
\text { American } \\
\text { received an } \\
\text { unconditional } \\
\text { basic income } \\
\text { what do you } \\
\text { think most } \\
\text { people would } \\
\text { do? }\end{array}$} \\
\hline & & $n$ & & $n$ \\
\hline Quit working or seeking work & $4.17 \%$ & 2 & $16.67 \%$ & 8 \\
\hline Reduce working hours & $10.42 \%$ & 5 & $27.08 \%$ & 13 \\
\hline Continue working & $43.75 \%$ & 21 & $27.08 \%$ & 13 \\
\hline $\begin{array}{l}\text { Apply the money towards major } \\
\text { financial goals such as education, } \\
\text { homeownership, or a small busi- } \\
\text { ness development }\end{array}$ & $39.58 \%$ & 19 & $10.42 \%$ & 5 \\
\hline $\begin{array}{l}\text { Apply the money towards a major } \\
\text { consumer purchase, such as a } \\
\text { vehicle, television, or appliance }\end{array}$ & $0.00 \%$ & 0 & $16.67 \%$ & 8 \\
\hline Other & $2.08 \%$ & 1 & $2.08 \%$ & 1 \\
\hline
\end{tabular}

From a more practical perspective, five people assumed that Americans would not significantly reduce their working hours simply because $\$ 1000$ per month is not enough to live on. Sample responses include "While $12 \mathrm{k}$ a year helps, if your [sic] at min wage that just lets you get a little less shitty apartment that's about it," "I think most would continue working as that would not be enough to sustain people," and " 1000 isn't enough to live on. They might reduce working hours, but most likely they'll continue working as they are."

Six respondents discussed their belief that most people would put money towards major consumer purchases rather than savings goals or living expenses. For example, they stated that "People like to buy things," "I've known a lot of people with limited incomes and that's what they would do [make large consumer purchases]," and "I think most people would want to keep their regular income and just want to buy stuff with it." While eight respondents chose "major consumer purchases" in the quantitative section, their qualitative responses may have been more in line with other themes such as engendering laziness or they may have been eliminated from qualitative coding as described in the procedures section.

Another six, however, believed that Americans would put the money towards major savings goals such as eliminating debt, retirement, education, homeownership, or small business development. They explained that, "Most people have nothing saved for retirement. I feel that this money would enable people to plan for the future," "I think people would use the opportunity to get ahead," and "I think most 
people are having trouble meeting these very basic expenses and would just put the money toward paying their debts or moving forward with life's basic goals."

\section{Discussion}

This survey of current and former American public assistance recipients reveals that while most respondents believe that receiving a basic income would not change their current work arrangements and would facilitate future financial stability (i.e., homeownership, education, and small business development), they were much more suspicious of other Americans. These responses, such as "Americans can be lazy" and especially "I don't know anyone like this but... a lot of folks want something for nothing" demonstrate the entrenchment of the Protestant, Conservative, and Neoliberal ideologies discussed earlier. There may also be a deeper psychological component to these reactions as well. A growing body of research suggests that political Conservatives hold a greater "negativity bias" than Liberals, in which one is more likely to assume the worst in others (Hibbing et al., 2014).

Meanwhile, ample evidence suggests that basic income does not lead to a sudden increase in dependence or negative behaviors. In addition to the findings discussed earlier, the recent Stockton, California, pilot with 100 low-income recipients found that approximately half of the $\$ 500$ monthly benefit was spent on groceries and utilities (Baker et. al, 2021). This has significant implications for the macro economy as increased local food spending through the existing SNAP program has a higher economic multiplier effect (program cost versus resultant GDP growth) than most public expenditures (Bolen \& Wolkomir, 2020). Advocates will need to work aggressively to address these misconceptions if they wish to see the current proliferation of basic income pilots translated to national policy.

Our study carries important limitations. First, what people say they will do versus what they actually do may be different things. Future research in this area ought to compare one's projected use of a basic income with their actual use of unrestricted funds such as the Earned Income Tax Credit or the 2020 CARES Act benefit. Furthermore, while the Prime Panels platform offers a more diverse sample than Amazon MTurk (Chandler et al., 2019), it still does not carry the same representative strength of a probability sample. Finally, because this survey was a pilot test of the instrument, we learned of several important categories that should have been considered: groceries, regular expenses (housing, bills, etc.) debt, childcare, and healthcare. It would also be informative to disaggregate some of the categories. For example, separating homeownership, small business development, and higher education.

It might also be useful to capitalize on these findings by examining whether different framings for a basic income change one's response to it. For example, would Americans react more favorably to an annual benefit rather than a monthly one? The relative political popularity of the Earned Income Tax Credit and other tax code programs suggests that it might. Furthermore, does one's support for UBI change with the amount of proposed benefit, i.e., $\$ 1000$ versus $\$ 500$ per month? Examining these questions will be critical for advocates seeking to make the case for a UBI to the American public. The psychological narratives that Americans construct about how a basic income is spent may be central to their support of the policy. 


\section{Appendix 1}

\section{Appendix A}

1. Which category below includes your age?
a. $18-20$
b. $21-29$
c. $30-39$
d. $40-49$
e. $50-59$
f. 60 or older

2. Are you White, Black or African-American, American Indian or Alaskan Native, Asian, Native Hawaiian or other Pacific Islander, or some other race?
a. White
b. Black or African-American
c. American Indian or Alaskan Native
d. Asian
e. Native Hawaiian or other Pacific islander
f. Some other race
g. Multiracial

3. What is your gender?
a. Male
b. Female
c. Non-binary/ third gender
d. Prefer not to say

4. Are you now married, widowed, divorced, separated, or never married?
a. Married
b. Widowed
c. Divorced
d. Separated
e. Never married

5. What is the highest level of school you have completed or the highest degree you have received?
a. Less than high school degree
b. High school degree or equivalent (e.g., GED)
c. Some college but no degree
d. Associate degree 

e. Bachelor's degree
f. Graduate degree

6. Which of the following categories best describes your employment status?
a. Employed, working 1-39 hours per week
b. Employed, working 40 or more hours per week
c. Not employed, looking for work
d. Not employed, NOT looking for work
e. Retired
f. Disabled, not able to work

7. How much total combined money did all members of your household earn in 2018 ?
a. $\$ 0-\$ 9,999$
b. $\$ 10,000-\$ 19,999$
c. $\$ 20,000-\$ 29,999$
d. $\$ 30,000-\$ 39,999$
e. $\$ 40,000-\$ 49,999$
f. $\$ 50,000-\$ 59,999$
g. $\$ 60,000-\$ 69,999$
h. $\$ 70,000-\$ 79,999$
i. $\$ 80,000-\$ 89,999$
j. $\$ 90,000-\$ 99,999=$
k. $\$ 100,000$ or more $=$

8. Have you ever received assistance from Temporary Assistance to Needy Families or as it was known prior to 1996, Aid to Families with Dependent Children?
a. Yes
b. No
i. If yes, for what years did you receive assistance?

9. Have you ever received assistance from the Supplemental Nutrition Assistance Program (sometimes known as Food Stamps)?
a. Yes
b. No
i. If yes, for what years did you receive assistance?

10. Have you ever received assistance from the government Unemployment Insurance program?
a. Yes
b. No
i. If yes, for what years did you receive assistance? 
11. Have you ever received assistance from Supplemental Security Income (sometimes known as disability)?
a. Yes
b. No
i. If yes, for what years did you receive assistance?

12. If, instead of traditional public assistance, you received an unconditional basic income of $\$ 1,000$ per month that came with no income limitations, no requirements to seek/maintain employment or other similar eligibility criteria, what would you do?
a. Quit working or seeking work
b. Reduce working hours
c. Continue working as I do now
d. Apply the money towards major financial goals such as education, home ownership, or a small business development (please explain).
e. Apply the money towards a major consumer purchase, such as a vehicle, television, or appliance (please explain).
f. Other (please explain)

13. In complete sentences, please elaborate on your response to the above question.

14. If, instead of traditional public assistance, every American received an unconditional basic income of $\$ \mathbf{1 , 0 0 0}$ per month that came with no income limitations, no requirements to seek/maintain employment or other similar eligibility criteria, what do you think most people would do?
a. Quit working or seeking work
b. Reduce working hours
c. Continue working as they do now
d. Apply the money towards major financial goals such as education, home ownership, or a small business development (please explain).
e. Apply the money towards a major consumer purchase, such as a vehicle, television, or appliance (please explain).
f. Other (please explain) 


\section{Appendix 2}

Table 2 Participant demographics

\begin{tabular}{|c|c|c|c|}
\hline & & $\mathrm{n}$ & $\%$ \\
\hline \multirow[t]{6}{*}{ Age } & $18-20$ & 0 & 0.00 \\
\hline & $21-29$ & 14 & 0.29 \\
\hline & $30-39$ & 18 & 0.38 \\
\hline & $40-49$ & 9 & 0.19 \\
\hline & $50-59$ & 3 & 0.06 \\
\hline & 60 or older & 4 & 0.08 \\
\hline \multirow[t]{7}{*}{ Race } & White & 39 & 0.81 \\
\hline & Black or African-American & 5 & 0.10 \\
\hline & American Indian or Alaskan Native & 0 & 0.00 \\
\hline & Asian & 0 & 0.00 \\
\hline & Native Hawaiian or other Pacific islander & 0 & 0.00 \\
\hline & Some other race & 1 & 0.02 \\
\hline & Multiracial & 3 & 0.06 \\
\hline \multirow[t]{4}{*}{ Gender } & Male & 27 & 0.56 \\
\hline & Female & 21 & 0.44 \\
\hline & Non-binary/third gender & 0 & 0.00 \\
\hline & Prefer not to say & 0 & 0.00 \\
\hline \multirow[t]{5}{*}{ Marital status } & Married & 11 & 0.23 \\
\hline & Widowed & 0 & 0.00 \\
\hline & Divorced & 9 & 0.19 \\
\hline & Separated & 1 & 0.02 \\
\hline & Never married & 27 & 0.56 \\
\hline \multirow[t]{6}{*}{ Education } & Less than high school degree & 0 & 0.00 \\
\hline & High school degree or GED & 9 & 0.19 \\
\hline & Some college but no degree & 12 & 0.25 \\
\hline & Associate degree & 9 & 0.19 \\
\hline & Bachelor's degree & 17 & 0.35 \\
\hline & Graduate degree & 1 & 0.02 \\
\hline \multirow[t]{6}{*}{ Employment status } & Employed, working 1-39 h per week & 12 & 0.25 \\
\hline & Employed, working 40 or more hours per week & 32 & 0.67 \\
\hline & Not employed, looking for work & 1 & 0.02 \\
\hline & Not employed, NOT looking for work & 1 & 0.02 \\
\hline & Retired & 0 & 0.00 \\
\hline & Disabled, not able to work & 2 & 0.04 \\
\hline \multirow[t]{6}{*}{ Household income } & $\$ 0-\$ 9,999$ & 3 & 0.06 \\
\hline & $\$ 10,000-\$ 19,999$ & 11 & 0.23 \\
\hline & $\$ 20,000-\$ 29,999$ & 9 & 0.19 \\
\hline & $\$ 30,000-\$ 39,999$ & 7 & 0.15 \\
\hline & $\$ 40,000-\$ 49,999$ & 1 & 0.02 \\
\hline & $\$ 50,000-\$ 59,999$ & 6 & 0.13 \\
\hline
\end{tabular}


Table 2 (continued)

\begin{tabular}{llll}
\hline & $\mathrm{n}$ & $\%$ \\
\hline$\$ 60,000-\$ 69,999$ & 4 & 0.08 \\
$\$ 70,000-\$ 79,999$ & 1 & 0.02 \\
$\$ 80,000-\$ 89,999$ & 2 & 0.04 \\
$\$ 90,000-\$ 99,999$ & 0 & 0.00 \\
$\$ 100,000$ or more & 3 & 0.06 \\
& Prefer not to answer & 1 & 0.02 \\
\hline
\end{tabular}

Funding This study was supported by funds from the Appalachian State University Wayne Duncan Award.

\section{Declarations}

Conflict of Interest The authors declare no competing interests.

\section{References}

Akee, R. K. Q., Copeland, W. E., Keeler, G., Angold, A., \& Costello, E. J. (2010). Parents' incomes and children's outcomes: A quasi-experiment using transfer payments from casino profits. American Economic Journal: Applied Economics, 2(1), 86-115.

Baker, D. A. C., Samra, S., Coltrera, E., Addo, M., Carlson, M., Crowder, P., Cusack, M., Elliott, S., Horn, D., Steckel, J., \& Zaghloul, T. (2021). Preliminary Analysis: SEED's First Year (p. 25). Stockton Economic Empowerment Demonstration. https://static1.squarespace.com/static/ 6039d612b17d055cac14070f/t/603ef1194c474b329f33c329/1614737690661/SEED_ Preliminary+Analysis-SEEDs+First+Year_Final+Report_Individual+Pages+-2.pdf

Basic Income Earth Network (BIEN). (2020). A history. Retrieved on October 3, 2020, from https:// basicincome.org/history/

Boddy, C. (2016). Sample size for qualitative research. Qualitative Market Research: An International Journal, 19(4), 426-432. https://doi.org/10.1108/QMR-06-2016-0053

Bolen, E., \& Wolkomir, E. (2020). SNAP boosts retailers and local economies. Center on Budget Policies and Priorities. https://www.cbpp.org/research/food-assistance/snap-boosts-retailers-and-localeconomies

Burtless, G. (1986). The work response to a guaranteed income: A survey of experimental evidence. In Conference Series Proceedings. Federal Reserve Bank of Boston. No., 30, 22-59.

Chandler, J., Rosenzweig, C., Moss, A. J., Robinson, J., \& Litman, L. (2019). Online panels in social science research: Expanding sampling methods beyond Mechanical Turk. Behavior Research Methods, 51(5), 2022-2038. https://doi.org/10.3758/s13428-019-01273-7

Creswell, J. W., \& Poth, C. N. (2017). Qualitative inquiry and research design: Choosing among five approaches (4th ed.). SAGE Publications, Inc.

Crossman, A. (2019). A Book Overview: The Protestant Ethic and The Spirit Of Capitalism. ThoughCo.

Davala, S., Jhabvala, R., Standing, G., \& Badgaiyan, N. (2017). Piloting Basic Income - A Legacy Study Final Report. SEWA Bharat and INBI, 5-17.

Food and Agriculture Organization (FAO) of the United Nations. (2016). Cash transfers: their economic and productive impacts Evidence from programmes in sub-Saharan Africa. http://www.fao.org/3/ a-i6156e.pdf 
Foster, A., \& Rojas, A. (2018). Program participation and spending patterns of families receiving government means-tested assistance. Monthly Labor Review. https://doi.org/10.21916/mlr.2018.3

Freeland, E. (2019). What do Americans think about universal basic income? USC Schaeffer Center. https://healthpolicy.usc.edu/evidence-base/what-do-americans-think-about-universal-basic-income/

Friedman, M. (2009). Capitalism and Freedom: Fortieth Anniversary Edition. University of Chicago Press.

Gilberstadt, H. (2020). More Americans oppose than favor the government providing a universal basic income for all adult citizens. Pew Research Center. https://www.pewresearch.org/fact-tank/2020/08/ 19/more-americans-oppose-than-favor-the-government-providing-a-universal-basic-income-for-alladult-citizens/

Goeury, H. (2016). Conditional cash transfers (CCTs) and neoliberalism in Latin America. ResearchGate, 6.

Hamilton, L. (2016). Incentives in the Temporary Assistance for Needy Families program: A review of the literature. Poverty \& Public Policy, 8(2), 141-149. https://doi.org/10.1002/pop4.134

Hanna, R. (2019). Dispelling the myth of welfare dependency. Harvard Kennedy School. https://epod.cid. harvard.edu/article/dispelling-myth-welfare-dependency

Hasdell, R. (2020). What we know about universal basic income: A cross-synthesis of review. Basic Income Lab, 27. https://basicincome.stanford.edu/uploads/Umbrella\%20Review\%20BI_final.pdf

Hibbing, J. R., Smith, K. B., \& Alford, J. R. (2014). Differences in negativity bias underlie variations in political ideology. Behavioral and Brain Sciences, 37(3), 297-307. https://doi.org/10.1017/ S0140525X13001192

Hughes, K. (2020). American President: Richard Milhous Nixon: "Domestic Affairs". The University of Virginia. Retrieved on October 3, 2020, from https://web.archive.org/web/20100407202356/http:// millercenter.org/academic/americanpresident/nixon/essays/biography/4

Ipsos. (2017). Poll conducted for University of Bath-institute for policy research: Universal basic income research. https://www.ipsos.com/sites/default/files/ct/news/documents/2017-09/omnibus-universalbasic-income-topline-2017.pdf

Jansson, B. S. (2014). The Reluctant Welfare State: Engaging History to Advance Social Work Practice in Contemporary Society (8 edition). Cengage Learning.

Jones, D., \& Marinescu, I. (2020). The labor market impacts of universal and permanent cash transfers: Evidence from the Alaska permanent fund. NBER Working Paper Series. 8. https://www. nber.org/system/files/working_papers/w24312/w24312.pdf

Kela. (2020). Results of Finland's basic income experiment: Small employment effects, better perceived economic security and mental wellbeing. https://www.kela.fi/web/en/news-archive/-/asset_ publisher/1N08GY2nIrZo/content/results-of-the-basic-income-experiment-small-employmenteffects-better-perceived-economic-security-and-mental-wellbeing

Litman, L., \& Robinson, J. (2020). Conducting online research on amazon mechanical turk and beyond (1st ed.). SAGE Publications, Inc.

Marinescu, I. (2017). No strings attached: The behavioral effects of U.S. unconditional cash transfer programs. Washington, D.C: Roosevelt Institute. http://rooseveltinstitute.org/wp-content/uploads/2017/ 05/No-Strings-Attached-050417-1.pdf

Marinescu, I. (2017). No strings attached: The behavioral effects of U.S. unconditional cash transfer programs. Roosevelt Institute. http://rooseveltinstitute.org/wp-content/uploads/2017/05/No-StringsAttached-050417-1.pdf

More, T. (2003). Utopia (P. Turner, Ed.; Reissue edition). Penguin Classics.

Nikiforos, M., Steinbaum, M., \& Zezza, G. (2017). Modeling the Macroeconomic Effects of a Universal Basic Income. Roosevelt Institute. http://rooseveltinstitute.org/modeling-macroeconomiceffects-ubi/

Rand, A. (1967). What is Capitalism? Ayn Rand Institute. https://courses.aynrand.org/works/what-iscapitalism/

Robins, P. K. (1985). A comparison of the labor supply findings from the four negative income tax experiments. The Journal of Human Resources, 20(4), 567-582.

Russell, B. (2013). Roads to Freedom: Socialism, Anarchism, and Syndicalism. HardPress Publishing.

Smith, N. A., Sabat, I. E., Martinez, L. R., Weaver, K., \& Xu, S. (2015). A convenient solution: Using MTurk to sample from hard-to-reach populations. Industrial and Organizational Psychology, 8(2), 220-228. https://doi.org/10.1017/iop.2015.29

Standing, G. (2017). Basic Income: A Guide for the Open-Minded. Yale University Press. 
Thompson, D. (2018). Busting the myth of 'welfare makes people lazy.' The Atlantic. https://www. theatlantic.com/business/archive/2018/03/welfare-childhood/555119/

Van Parijs, P. (2004). Basic income: A simple and powerful idea for the twenty-first century. Politics \& Society, 32(1), 20. https://doi.org/10.1177/0032329203261095

Widerquist, K. (2005). A failure to communicate: What (if anything) can we learn from the negative income tax experiments? Journal of Behavioral and Experimental Economics, 34(1), 49-81.

Zogby, J. (2017). Do Americans want a universal basic income? John Zogby Strategies. Retrieved on October 14, 2020, from https://johnzogbystrategies.com/do-americans-want-a-universal-basic-income/

Publisher's Note Springer Nature remains neutral with regard to jurisdictional claims in published maps and institutional affiliations. 